\title{
A brief reflection of International Microbiology's history and future direction
}

\author{
José Berenguer ${ }^{1}$ - Antonio Ventosa ${ }^{2}$ \\ Published online: 14 June 2018 \\ (C) Springer International Publishing AG, part of Springer Nature 2018
}

New technologies increase the rate at which every kind of announcement and discovery is presently spread among the media and social networks, independently of this being based on real grounds, on misinterpretation of facts, or even directly on manipulation with specific aims. This is also happening with hypothetical pseudo-scientific discoveries, which are gaining ground in parts of society through their uncontrolled diffusion in mass media. As scientists, it is our responsibility to fight the diffusion of false or unreliable science through the channelization of our research through peer-review systems that guarantee the quality, reproducibility, and scientific impact of our results. At the same time, the scientific journals have to adapt to the new technologies to allow a rapid dissemination of the research through the adoption of either a full electronic format or advanced online versions of the articles, while keeping the quality control in place that peer-review systems provide.

International Microbiology is the official scientific journal of the Spanish Society for Microbiology, but it is not one of the several new journals that have appeared in the last few years. It has been around more than 70 years. The first scientific publication of the "Asociación de Microbiólogos Españoles" (Spanish Association of Microbiologists), the society that joined the most prominent microbiologists of Spain in the late 1940s, was born in 1947 with the name Microbiología Española (Spanish Microbiology), with the support of the Institute of Microbiology Jaime Ferrán from

José Berenguer

jberenguer@cbm.csic.es

$\triangle$ Antonio Ventosa

ventosa@us.es

1 Center for Molecular Biology Severo Ochoa, Universidad Autónoma de Madrid- Consejo Superior de Investigaciones Científicas, 28049 Madrid, Spain

2 Department of Microbiology and Parasitology, Faculty of Pharmacy, University of Sevilla, 41012 Sevilla, Spain the National Research Council (CSIC). Though written entirely in Spanish, its international idea was presented in an editorial in the first edition by the president of the society, in those times Prof. Juan Marcilla Arrazola, who wrote that the journal was "a way to open our society to the International Society of Microbiology." The editorial ended with the quote: "God protect our effort for the good of Spanish Science," likely as a prescient idea that in those times Science in Spain required every kind of protection (Marcilla Arrazola 1947). Despite the fact that Microbiología Española published articles only in Spanish, it was well received and gained international recognition over the years, being indexed in several international collections.

In 1986, the CSIC decided to close the Institute of Microbiology "Jaime Ferrán”, and as a consequence, Microbiología Española officially ceased to be published after 39 years. During this time, the journal had published 655 articles, included among them renowned works such as the first description of the genus Bordetella (Moreno López 1953). Fortunately, the publication service of the CSIC digitized the full collection, currently available online through the web page of the Spanish Society for Microbiology (http:// www.semicrobiologia.org/sec/revista_hist2.php).

Being aware of the pending discontinuation of the journal, the then-named Sociedad Española de Microbiología (Spanish Society for Microbiology, SEM) decided to start a second scientific journal in 1985 with the name Microbiologia $S E M$, this time under the exclusive responsibility of the Society. As the president of the SEM at that time, Prof. César Nombela wrote in its presentation editorial a prophetic idea of the future of scientific literature: "We believe that in these times of explosive growth of scientific literature, those publications managed by scientific societies can, in some sense, be the most competitive from the point of view of quality, since they can do it without any other concern." Microbiología SEM started publishing two issues per year, and finally achieved quarterly frequency under the direction of Prof. Ricardo Guerrero. During this period, the journal 
published around 390 articles and comments authored by national and international authors, many of them entirely in English. In 1998, Prof. Guerrero, with strong support from Prof. Linn Margulis, promoted the internationalization of the journal, adopting a new policy of publishing only in English and changing its name to International Microbiology. The journal acquired regularity and prestige, and was included in the Journal Citation Index and made accessible online in open access as this has been and still is an exciting development in research publishing (Van Noorden 2013). However, the idea of also offering a place for publication without publishing charges to authors with limited research funds has prompted us to modify our publication model policy. Under these considerations, in 2017, SEM and Springer Nature agreed on a new publication model for International Microbiology under the imprint Springer. The journal is now published as a subscription journal with optional open access (hybrid journal).

The aim of SEM in this new era of the journal is to claim and promote microbiology not just as a foundation of modern biology, but also as a growing science whose relevance in connection not just to "bad microbes" producing infectious and re-emerging diseases, every day more resistant to antibiotics, but also with the impressive beneficial and evolutiondriving effects produced by normal microbiota on human, animals, and plant health, or the revisited role that microorganisms have on carbon and nitrogen cycling affecting the global ecology fate of the Earth (de Vos and de Vos 2012; Singh et al. 2010; Zilber-Rosenberg and Rosenberg 2008). Biotechnological applications of microorganisms in biodegradation, bio-production of goods or the use of microbe elements as tools for DNA amplification (PCR) or gene edition (CRISPR-Cas) are also improvements based on modern microbiology. Toward this goal, our purpose is continuing to publish articles with the highest standards of scientific rigor, quality, and peer-review, in all fields related to microbiology, from viruses to bacteria, archaea, protozoa, and fungi. Review articles such as those published in the past (Benitez et al. 2004; Martinez et al. 2005) and more recently (Escudero and Mazel 2017) are also welcome on this endeavor.

We invite all microbiologists to take a look at the journal's website (www.springer.com/10123) and to consider International Microbiology as a publication platform to present and disseminate their research for a global readership.

\section{References}

Benitez T, Rincon AM, Limon MC, Codon AC (2004) Biocontrol mechanisms of Trichoderma strains. Int Microbiol 7:249-260

de Vos WM, de Vos EA (2012) Role of the intestinal microbiome in health and disease: from correlation to causation. Nutr Rev 70(Suppl 1):S45-S56

Escudero JA, Mazel D (2017) Genomic plasticity of Vibrio cholerae. Int Microbiol 20:138-148

Marcilla-Arrazola J (1947) Editorial. Microbiol Espanol 1:5-7

Martinez AT, Speranza M, Ruiz-Duenas FJ, Ferreira P, Camarero S, Guillen F, Martinez MJ, Gutierrez A, del Rio JC (2005) Biodegradation of lignocellulosics: microbial, chemical, and enzymatic aspects of the fungal attack of lignin. Int Microbiol 8:195-204

Moreno-López M (1953) El género Bordetella. Microbiol Espanol 5: 177-181

Singh BK, Bardgett RD, Smith P, Reay DS (2010) Microorganisms and climate change: terrestrial feedbacks and mitigation options. Nat Rev Microbiol 8:779

Van Noorden R (2013) Open access: the true cost of science publishing. Nature 495:426

Zilber-Rosenberg I, Rosenberg E (2008) Role of microorganisms in the evolution of animals and plants: the hologenome theory of evolution. FEMS Microbiol Rev 32:723-735 